\title{
SPOTTED
}

\section{Spotted around the web: Sleep features, seizure genes, pandemic effects}

\author{
BY JILL ADAMS
}

21 JANUARY 2022 